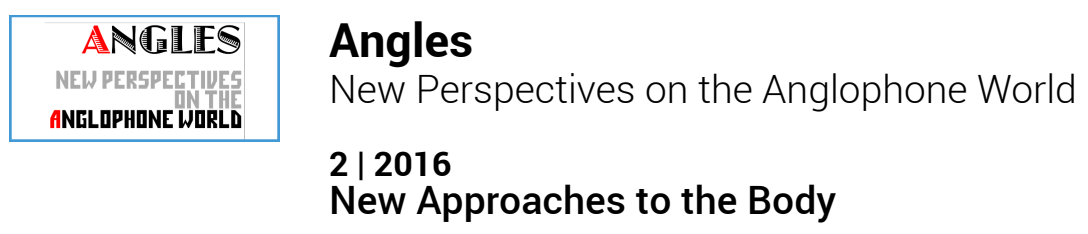

\title{
Video introduction to issue 2
}

\section{Anne-Laure Fortin-Tournès}

\section{(2) OpenEdition}

\section{Journals}

Electronic version

URL: https://journals.openedition.org/angles/1772

DOI: 10.4000/angles. 1772

ISSN: 2274-2042

\section{Publisher}

Société des Anglicistes de l'Enseignement Supérieur

\section{Electronic reference}

Anne-Laure Fortin-Tournès, "Video introduction to issue 2", Angles [Online], 2 | 2016, Online since 01 April 2016, connection on 07 June 2022. URL: http://journals.openedition.org/angles/1772 ; DOI: https://doi.org/10.4000/angles.1772

This text was automatically generated on 7 June 2022

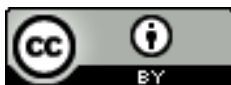

Angles est mise à disposition selon les termes de la Licence Creative Commons Attribution 4.0 International. 


\title{
Video introduction to issue 2
}

\author{
Anne-Laure Fortin-Tournès
}

This media file cannot be displayed. Please refer to the online document http:// journals.openedition.org/angles/1772

\section{Transcript:}

Welcome to the second issue of Angles. My name is Anne-Laure Fortin-Tournès and I am this issue's guest editor.

2 This issue contains 13 contributions in various forms and media representing new approaches to the body, performance, experimentations. This issue means to explore new ways of representing the body, of relying on its performing and performative capabilities.

3 We'll see that as the material body seems to be receding in our digital cultures. Many cultural artifacts combine sanitization and semiotization which allows for new nomadic forms of corporeality to appear.

4 The first contribution by Lara Delage-Toriel analyses the body as a prime agent in McCann's narrative plots. Semiotized by a text which it summarizes in turn, the moving body is not only a central theme but also a textual matrix in McCann's fiction which engages the body in the literary process both as sense making and sensitive entity.

5 François Hugonnier also makes a point about the importance of physicality to writing and literary creation. He shows that Paul Auster's novels are fuelled by bodily failures and functions. Auster's breakthrough experience of a real contemporary dance performance he witnessed in 1978 actually changed his approach to language, style and literature in general.

6 Alexandre Galopin and Natacha Grimaud's dance video clip for its part explores the possibilities for the dancing body to perform on its own and in relation to another body in a peaceful, natural setting according to a triptych-based pattern. 
7 In her short fictional piece of practice-led research, Elsa Cox introduces us to the spectral presence of a female body through the evocation of the silk bias-cut dress so as to raise the key issue of the spectral presence in language of the material body. In 'The brain without the body,' Marion Roussel goes to the roots of the uncanny feeling we get when the frontier between the material and the immaterial or virtual body gets blurred. She bases her demonstration on Marcos Novak's experiments in digital architecture. His explorations of the insides of his own brain, for instance, which he externalizes and transforms into an immersive experience for the visitor.

9 The impact of new technologies on the way we conceive of our bodies is analyzed further in Claire Larsonneur's contribution which focuses on the dissolution of the boundaries between the material and the virtual in our digital age.

10 In the next contribution, Charles Joseph chooses the cultural studies approach to explore the relation between real and virtual Los Angeles so as to suggest that L.A.'s urban sprawl is shaped by organic preoccupations.

11 Sarah Hatchuel and Sylvaine Bataille's video clip essay on the centrality of the body to acting in Lost insists on the importance of the actors' bodies to the series. The script was indeed written for the actors and the characters they embodied often had to evolve to fit the actor's own change in physical and personal characteristics.

12 In the next contribution, Xavier Lemoine shows how the Big Art Group's Broke House uses queer performances and transgressive bodies to mediatize gender, racial, sexual and social questioning of traditional representational norms. The Big Art Group which constructs theatre through queer cyber performances blurs the line defining the normative bodies, subjectivities and technological performances.

13 The one last piece in our issue about body is Clare Hayes-Brady's investigation of the rules of objects in Jeffrey Eugenides's The Virgin Suicides and Orhan Pamuk's The Museum of Innocence where the departed female body remembered through a number of memorabilia by the narrators tends to draw the reader into a voyeuristic position.

Finally, this issue's 'Varia' section consists of two contributions by Wilfrid Rotgé and Françoise Král. The first contribution is a linguistic analysis of the deceptively simple coordinator 'and' in Janet Frame's fiction, while the second paper presents us with an A to $\mathrm{Z}$ of the diasporic body which explores the various facets of diasporic theory and critique.

15 I hope you will enjoy this issue.

\section{ABSTRACTS}

This video introduces the thematic contributions on 'New Approaches to the Body'. The guest editor then introduces the two contributions in the Varia section. 
La vidéo commence par présenter les contributions thématiques sur «Les nouvelles approches du corps: Performance et expérimentations ». La responsable du numéro présente ensuite les deux contributions de la section Varia.

INDEX

Mots-clés: vidéo, corps, langue, littérature, danse, humanités numériques, recherche expérimentale

Keywords: video, body, language, literature, digital humanities, experimental research

\section{AUTHOR}

\section{ANNE-LAURE FORTIN-TOURNÈS}

Guest editor of Issue 2. Professor at the Université du Maine. Her research focuses modern British literature, the relationship between text and image, art, trauma theory, the representations of the body, and women's writing. 